\title{
The Hinge Areas for Urban Regeneration in Seaside Cities: the High Line in Manhattan, NYC
}

\author{
Eleonora Giovene Di Girasole $e^{1, a}$
}

${ }^{1}$ National Research Council of Italy (CNR), Institute for Service Industry Research (IRAT), via Guglielmo Sanfelice, 8, Naples, Italy

ae.giovenedigirasole@irat.cnr.it

Keywords: Seaside City, Waterfront Development, Hinge Areas, Integrated Urban Regeneration, High Line.

\begin{abstract}
Aim of this paper is to reflect on how cities, which are growing on the coast and are rediscovering their waterfront, can represent a privileged laboratory to wonder about the destiny of the modern metropolis, through the identification of innovative models of development, through the assumption of the sea as a full of opportunities horizon, a sort of epicenter of a new movement going from the coast to the inner part of the city. That means carrying out regeneration processes in which cities, starting from their maritime culture, realize complete and shared urban transformations. Thus, in continuation of cities' maritime tradition, integrated transformations aimed at environmental, economic and social development have been carried out by involving several actors and resources, with consequences on the whole urban environment and not only on the narrow coastline. Therefore, the work should be done not only on the narrow line of waterfront, but in a way to involve also the remaining part of the city by redesigning the hinge areas which represent a connection between waterfront and city with its community. In this paper it is showed the case study of the requalification, demanded from the local community, of the High Line in New York, an elevated Railroad placed in residual spaces between sea and city. It represents one of the best practices of regeneration of hinge areas integrated in the waterfronts redevelopment policy and regeneration of the city reached with participation of the urban community.
\end{abstract}

\section{Urban Maritime Culture and regeneration of Seaside Cities: an integrated approach}

The requalification of waterfront is one of the emerging themes in the XXth century urban policy of the seaside cities which have to face their conversion as well as their requalification, taking back the control over the sea and the bordering areas which are again part of the city [1] [2] [3] [4] [5].

During the last years many seaside cities (such as New York, Genoa, Marseille, etc.), have developed urban-harbor recovery process and transformation plans for their waterfronts, in order to recover a connection with sea throughout various approaches, political choices, projects, actors and resources [6] [7] [8]. These experimentations are surely one of the greatest opportunities of urban development of the contemporary age [9] [10].

Yet, these interventions, although valid, remain superficial, since they seldom weigh on regeneration of the city but usually stop along the boundary, with actions which are not fully integrated in an overall development of city and specifically of its community.

These interventions should not only aim at changing or requalifying parts of the city, but they should represent a wider plan of regeneration, through which city, starting from its maritime culture, can realize complete and shared urban transformations. Maritime culture represents the will of realizing a complete redefinition of the urban structure starting from its historic relation with sea, through the harmonious cohesion between maritime culture and urban one [11], whose effect is called by Konvitz "Urban Maritime Culture" [12], which allowed cities to realize those advances that led to urban, economic and social progress in the past.

That is to say contexts in which "integrated urban transformations" took place through a shared vision of urban development based on the recovery of cities' maritime culture. The aim was the 
achievement of targets as "urban and environmental" development as well as "maritime economy" development and the improvement of the life quality and the local identity, through those integrated processes (top down and bottom up) which involve different actors and resources. In so doing strategies and actions involving the whole city and not only the narrow coastline have been carried out (Fig.1).

This means involving also the important areas nearby the waterfronts, that is to say the so called between spaces amid the city and the coastline that represent the areas of connections with the rest of the city. These weak fronts are generally not engaged in the process of regeneration of the areas in which transformation is more profitable. These residual areas between waterfronts and cities (often they are barriers, disused areas, building sites, sites stuck between infrastructural network, suburbs, etc.) can be seen and treated in the urban projects as hinge areas [13], where the interactions among parts is possible.

These spaces can be seen as projected toward horizon but, at the same time, projected toward the city too, so that they become a plateau to build new relations and functions on, or a way to represent a connection amid the context and the urban community.

At the same time in dynamic, changeable and often conflicting contexts, it is pivotal, for the sustainable development of the city, the partnership-negotiation among actors (authority, institutions, entrepreneurs, associations, citizens, etc) who agree to take part in this shared vision of the matter.

In this context, arises the role played in urban community, associations and stakeholders in defining, implementing plans or programs, and proposing transformative interventions of the waterfront. In some cases "bottom-up" processes, can divert or make more effective the traditional "top down" processes, making clear the meaning that some areas, not in proximity of the coast, and consequently not involved in a requalification processes, may have.

This makes possible to organize transformations compatible with the territories and with the communities they are integrating with, especially in highly sensitive and humanized areas such as the coastline.
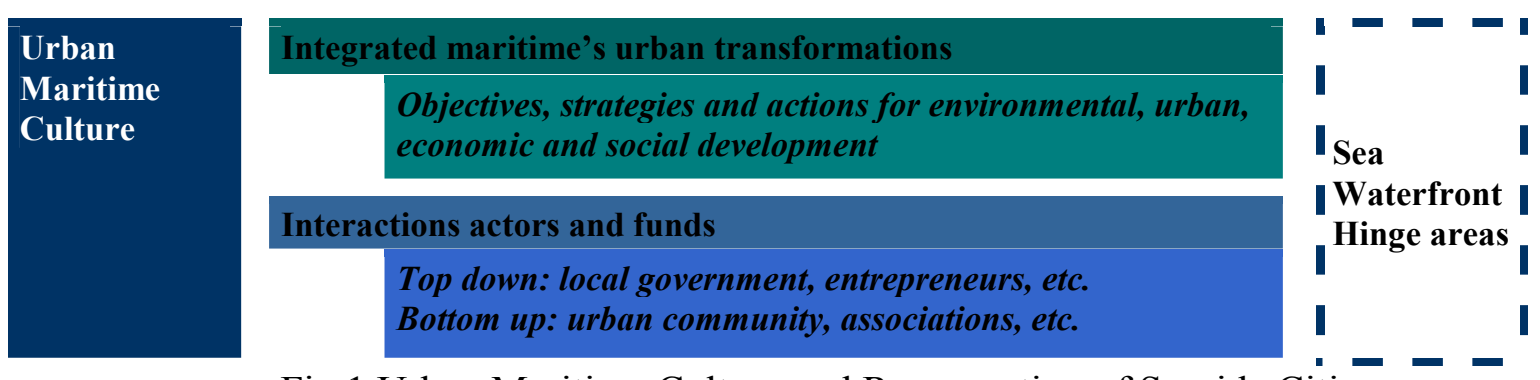

Fig.1 Urban Maritime Culture and Regeneration of Seaside Cities

According to this kind of approach, we have analyzed the interesting case study in the City of New York. The paper aims to analyzing the recent recovery process for what concerns the traditional relation that this city has with sea, thanks to the "Waterfront Plan for New York City" and the "Manhattan's West Side Development" [14] [15], adopted during the Bloomberg Administration as the concept of the city for 2020. In particular the requalification of the High Line, an elevated Railroad placed in a residual spaces between sea and city, is part of a bigger and longer transformation process of New York City's waterfront redevelopment and rezoning of West Chelsea District.

The intervention for the preservation and reuse of High Line arises from the opposition of the local community toward its demolition in order to realize its requalification.

Later this bottom up approach gave the Administration the opportunity to realize Manhattan's west side development and, on the one hand, to produce a reinterpretation of the public open space between sea and city, facilitating the reuse of the High Line as a unique linear open space, and enhancing the West Chelsea neighborhood's thriving in art gallery district. Moreover, it represented the opportunity for new residential and commercial development of the neighborhood. The case study represents one 
of the best practices of regeneration of hinge areas integrated in the redevelopment waterfronts policy and a growth opportunity for the city.

\section{New York City: Waterfront and Manhattan's West Side development}

The New York City's waterfront, which has a rich maritime history dating back to the 17th century, is characterized by 520 miles of coastline bordering ocean, river, inlet and bay. The New York Bay is the collective term for the marine areas surrounding the entrance of the Hudson River into the Atlantic Ocean. Upper New York Bay and Lower New York Bay, connected by The Narrows, are its two largest components. In particular the Upper New York Bay, crossroads between the ocean and inland waters, is the centre of a metropolitan settlement system that has been developed from Long Island to New Jersey by using water as a factor of cohesion.

The New York City's waterfront is at the centre of a redevelopment process. In 2011 the "Waterfront Vision and Enhancement Strategy" was pronounced following the guidelines of the 1992's city planning, a co-op plan intended to redesign 520 miles of the city's waterfront. The plan is divided into two parts: the "Vision 2020. New York City Waterfront Comprehensive Plan", which denotes the long-term goals for the next 10 years, and the "New York Agenda Waterfront City Action", consisting in 130 priority projects to be completed in three years. The latter is going to integrate a series of redevelopment interventions for both the waterfront and the area around it, with a major focus on the requalification of the public space.

"Vision 2020" is characterized by an extensive public outreach, including public meetings in all five boroughs and discussions with thousands of communities and waterfront stakeholders, lasted more than a year. Instead, in the "New York City Waterfront Action Agenda" are presented the 130 priority projects to be implemented over the next three years in order to realize the eight goals. These interventions are integrated actions not only along the waterfront but also in the areas immediately forthcoming, the ones in which the redevelopment and the increase of public space become the central spine of process [14] [15].

Public space and the adjacent upland communities are extremely important in the redevelopment process. Since, approximately 220 linear miles of shorefront parks or publicly accessible waterfront areas have been created and this has made New York City's waterfront more than ever active.

Since New York's 520 miles of coastline are diverse, each segment requires a local strategy. For the purposes of the plan, the city is divided into 22 segments or reaches. For these 22, site-specific projects will enhance public access, maritime industry, water recreation, natural environment, new development, and other activities. Local stakeholders and community planners discussed local waterfront issues and identified planning opportunities.

The specific proposals on the waterfront in the "Reach 3 - Lower West Side Manhattan", that includes the Hudson River from Chambers St. to W. 59th St. and the neighborhoods of TriBeCa, SoHo, West Village, Chelsea, Clinton, provided the expansion of Hudson River Park and the improvement of pedestrian and bicycle access to park from upland neighborhoods. In particular, along the Hudson River, up to W. $30^{\text {th }}$, were provided a series of interventions for:

- Pier 52: provide perimeter waterfront access around new waste-transfer station;

- Pier 54: pursue funding and development of park;

- Pier 57: advance plans made by Hudson River Park Trust and its private partner for a multi-use pier, including public market, art gallery, etc, and explore opportunities for in-water recreation based, and possibility to redevelopment the St. Heliport's areas [15].

In this process of NYC waterfront redevelopment the project of the High Line requalification is included. The latter crosses three of the most dynamic districts in Manhattan (the Meatpacking District, West Chelsea, and Hell's Kitchen/Clinton) launching the regeneration of those between spaces among waterfront and city.

This intervention represents a fundamental element for Manhattan's west side development, with the participation of the owners of "Friends of the High Line" association (whose role was essential to 
prevent its demolition and to recover significant funding for its transformation), so that it was possible to turn the High Line and the neighboring areas in hinge areas between sea and city.

\section{Hinge Areas: the High Line between sea and the city}

Since the '90s in this former industrial area, that was previously characterized by the presence of industrial warehouses, piers and the West Side Freight elevated Railroad (also known as "High Line"), a spontaneous process of renewal of post-industrial buildings has been started by urban community. This process has subsequently been patronized by the Department of City Planning's with the bill of "Special West Chelsea District Rezoning" (Fig.2), which helped to carry out the turning of the High Line into a public park, as well as a big improvement to the buildings and the public space right by the waterfront which, in return, contributed to the improvement of the whole neighborhood, attracting, thus, further investments.

The High Line, created between 1929 and 1934, served the industrial and productive districts of Manhattan's west side. Since 1980 the disused line, with some sections demolished in 1960 and in 1991, has fallen into neglect. In fact, in the Mid-1980s, a group of property owners lobbied for demolition of the entire structure. Members of this group owned lands under the High Line that were purchased at prices reflecting the High Line's easement. A battle against the demolition started in courthouse too and in the 1999 the residents of the High Line neighborhood founded the "Friends of the High Line", for the High Line's preservation and reuse as public open space.

Between 2001 and 2002 a planning study was realized and it was jointly produced by the Friends of the High Line and the Design Trust for Public Space for "Reclaiming the High Line", which laid out a planning framework for the High Line's preservation and reuse. In March 2002, the City Council produced his first act for the High Line's reuse and, at the same time, the Friends of the High Line realized a study which showed that the project was economically rational: new tax revenues created by the public space would be greater than the costs of construction [16]. Thus began a process, lasted until 2012, through which the City takes ownership of the High Line from CSX Transportation, which donates the structure, and the City and CSX signed a Trail Use Agreement.

The redevelopment of the High line provided the opportunity to create a bigger new public open space and weak front was turned into hinge areas, a privileged place with open view on the city and sea.

The project (which was the result of an architectural competition) made by James Corner Field Operation in cooperation with Diller\&Scofidio+Renfro and Piet Oudolf, person in charge of the botanic plan, saw the preservation of the original cast-iron structure that supported the rail tracks [17].
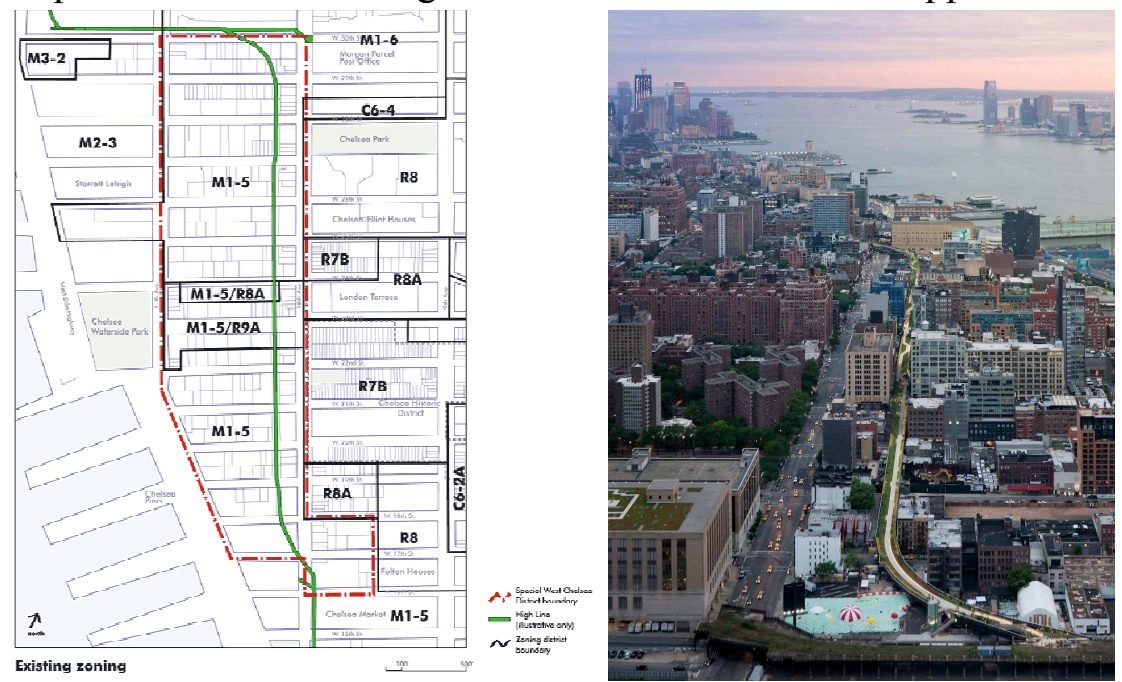

Fig.2 Special West Chelsea District Rezoning and High Line

These tracks have been replaced by a series of lawn wooden chairs. The park stretches through the surrounding buildings, and is characterized by a scenic and carefully planned game of visuals which 
creates a stunning view. Along the High Line, there are places with specific peculiarity that pay attention to the context privileging the view of the city; the piers and the Hudson River provides lift system intersection with the existing buildings by constructing a real urban story going through the quarters. Nature, in its spontaneity, is at its best and gives the impression that it has taken a hold of the High Line, totally transmuting it for the better. The presence of the sea is always a reference, a horizon to look at for those who walk along the High Line.

The process of regeneration of High Line, which was born from bottom up thanks to the role of the urban community, has been patronized by the Department of City Planning's, and has been inserted in the "Special West Chelsea District Rezoning". When the High Line was built in the 1930s, these neighborhoods were dominated by industrial and transportation uses. Now many of the warehouses and factories have been converted to art galleries, design studios, retailers, restaurants and residences.

West Chelsea was an area in transition which, especially in the central and southern portions of the area, had in large part given way to auto-related uses, including auto-repair, parking, and vehicle storage. Manufactures were used not only for residential purposes, but also for commercial ones, firstly in the form of art galleries and museums.

In 2005 the City Council approved the Department of City Planning's proposals for zoning text and map amendments affecting the West Chelsea area in Community District 4 Manhattan. The proposal would create the "Special West Chelsea District Rezoning" to provide opportunities for new residential and commercial development, facilitate the reuse of the High Line elevated rail line as a unique linear open space, and enhance the neighborhood's thriving art gallery district [18].

At the same time, aside from the new residential and commercial development, the enhancement of the district was carried out with the construction of a new public open space, through the use of the High Line as a "green space". Also the transformation of the buildings on its edges is designed to extend these features by checking alignments, distances and heights.

The "Special West Chelsea District Rezoning" contains provisions intended to enhance the proposed High Line open space and to ensure that adjacent developments engaged with and relate to the High Line. In order to encourage preservation of light and air around the High Line, the proposal would allow development rights to be transferred from High Line properties to designated receiving sites within the "Special West Chelsea District". New development along Tenth Avenue, adjacent to the High Line, would also be subjected to a series of building bulk and use controls to encourage connections to the High Line and the preservation of light, air and views (Special West Chelsea District Rezoning and High Line Open Space EIS, 2005). In other words, the "Special West Chelsea District Rezoning" wants to realize a residential and tertiary regeneration of the area and at the same time improve the new linear park facilitating the reuse of the High Line as a public open space by preserving views, light, and air and by providing regular public access points from ground level to the High Line level (Fig.3).

The "West Chelsea Special District" has fostered along the High Line and in the West Chelsea neighborhood, the building of 1,374 new housing units and 500,000 square feet of commercial office space. This intervention also managed to attract several sponsors whose investments greatly helped the neighborhood and waterfront's overhaul. As a matter of fact, the new IAC Center, designed by architect Frank O. Gehry, was built along the High Line, as well as the new apartment tower, designed by Jean Nouvel, or the new downtown Whitney Museum of American Art by Renzo Piano.

Currently, the path of the High Line extends from Gansevoort Street to the thirtieth street and, afterwards, it will end crossing the old rail yards between 30th and 34th street, going to Hell's Kitchen neighborhood where the High Line will become part of the "Hudson Yards Redevelopment Project", a new urban settlement. This new district will develop in an area of over 1 million square meters, with offices, residences, commercial uses, cultural centers, where the High Line will play a predominant role, drawing the pedestrian paths. Even in this case, the upgrading involves brownfield areas between the city and sea.

"What's most striking in this spectacular and repeated vindication of horizontality in the vertical city par excellence is the revolutionary force of the quiet ordinariness of the project and its apparent 
mimicry: it recreates its minimalist solutions and scales of a necessary detail needed in a urban story capable of calling into question established building rules and rethinking relations and hierarchies between the blocks intercepted in the grid» [19].

The example analyzed show, therefore, how the redevelopment of the waterfront and also of the areas immediately close to it will lead to sustainable development of the whole city by giving these tumbledown areas of the city a new role and, meanwhile, preserving the identity and cultural mixitè.

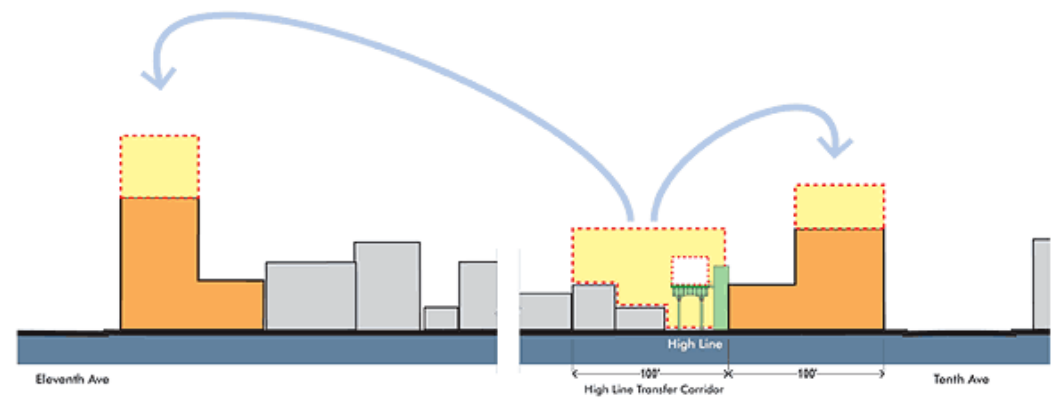

Fig.3 Spatial diagrams of the new building rules in the "Special West Chelsea District Rezoning"

\section{Concluding Remarks: hinge areas and urban community role for the seaside city regeneration}

The analysis of New York case study shows how this city, in continuation of its maritime culture and starting from its historic relations with sea, is going through a general and integrated redefinition of its urban structure, through the projection of sea toward city. The eight goals which are the core of the "Vision 2020: Comprehensive Waterfront Plan", established through a participatory process including the urban community, are achieved by means of actions which, according to the analysis of the interventions done, (Waterfront Action Agenda. Transforming New York City's Waterfront. One-Year Progress Report: May 2012) [14], affect environment as well as water, economy, work, houses, public open spaces, urban community and so on, so that to fulfill the starting hypotheses.

It's exactly in this process that the High Line's park project is integrated. The park is located in a broader process of New York City waterfront redevelopment and in the green strategy of the Bloomberg's Administration. The recovery and the transformation of the High Line originate from the local community's desire to regain a District's symbol which is seen as a fundamental architectural element and a public open space. With its integration Manhattan grid, new visuals, relations and geometry are created.

A weak front, placed in a between spaces, amid waterfront and city, becomes the starting point for the district's redevelopment. The integration of this project in "Special West Chelsea District" has turned these between places into hinge areas, leading to further occasions of urban regeneration and socio-economic development, interrelating the interventions along the waterfront established by the Administration with the rest of the city and its community. The plan helps «to safeguard the High Line, transferring development rights, and to allow art galleries survive by leaving the middle of the blocks as commercial space and the highways as residential» [19]. This was possible also thanks to the relation grown among the association, the Administration and the real estate promoters.

That shows the necessity to identify and follow strategies in order to involve citizens, public and private capitals. These strategies become opportunities for development and improvement of the between spaces, the places between city and sea, representing therefore the hinge projects to sustainable development of the whole city.

The case study shown as the redevelopment of the residual spaces - weak fronts, but important areas because of their role of connecting areas with the rest of the city - and on their necessary involvement of a wider process of regeneration of the city, allows to give these areas of the city a new role, preserving the identity and the social and cultural mixitè.

Thus this example shows how it is important to operate non only on the narrow coastline and how engaging territories and living behind communities may represent a multiplier factor in these 
processes of regeneration. This is an important topic that both research and architectural practice should deepen in the next years, in particular in those cities that are facing transformation of port and behind port areas.

\section{Acknowledgements}

The paper is a work in progress of the research project "Urban strategies for contemporary city: multiculturalism, identity, recovery and valorization", coordinated by Massimo Clemente, in (and funded by) National Research Council of Italy (CNR), Institute for Service Industry Research (IRAT).

\section{References}

[1] M. Carta, in Governare l'evoluzione. Principi, metodi e progetti per una urbanistica in azione, edited by M. Carta, Franco Angeli, Milano (2010)

[2] R. Pavia: in Periferie? Paesaggi urbani in trasformazione, edited by AA.VV., Di Baio, Milano (2005)

[3] R. Marshall: Waterfront in Post-Industrial Cities, Spon Press, London (2001)

[4] R. Bruttomesso: Waterfront. Una nuova frontiera per le città sull'acqua, Centro Internazionale Città d'Acqua, Venezia (1993)

[5] B. S. Hoyle: City-ports, coastal zone and regional change: international perspectives on planning and management, John Wiley and Sons Ltd, United Kingdom (1996)

[6] R. Pavia, M. di Venosa: Waterfront. Dal conflitto all'integrazione. From conflict to integration (List, 2012)

[7] M. Savino: Waterfront d'Italia. Piani, Politiche, Progetti, Franco Angeli, Milano (2010)

[8] L. Fonti: Porti-città-territori. Processi di riqualificazione e sviluppo, Alinea, Firenze (2010)

[9] O. Giovinazzi: Città portuali e waterfront urbani: costruire scenari di trasformazione in contesti di conflitto. Méditerranée [on line], 111 (2008), p.69

[10] M. Bradaschia: Decalogo post-urbano , Meltemi, Roma (2003)

[11] M. Clemente: Città dal mare. L'arte di navigare e l'arte di costruire le città, Editoriale Scientifica, Napoli (2011)

[12] J. W. Konvitz: Port cities and Urban History. Journal of Urban History, Vol.19, 3 (1992), p.19

[13] E. Giovene di Girasole: Waterfront and City: Redevelopment and Urban Quality. BDC, Vol. 12, 1 (2012), p.201

[14] Information on http://www.nycedc.com

[15] Information on http://www.nyc.gov

[16] Information on http://www.thehighline.org

[17] Information http://www.dsrny.com

[18] H. Platt Rutherford: The Humane Megacite. Trasforming New York's Waterfront. Environment Magazine, vol. 51, 4 (2009), p.62

[19] C. Gasparrini, V. Sassanelli: New York, Manhattan. The High Line Park. Monograph.it, 2 (2010), pp.300-357 